\title{
The Relationship between Teacher Expectations and Student Achievement in the Teaching of English as A Foreign Language
}

\author{
Iakovos Tsiplakides \& Areti Keramida \\ Corresponding author: Areti Keramida, Nikis Street, Ioannina, Greece \\ Tel: 30-26-5104-9753Ｅ-mail: akeramida@hotmail.com
}

\begin{abstract}
Research on second and foreign language learning suggests that the expectations that teachers form for their students can often have an impact on students' behavior and achievement. Some teachers tend to convey differential expectations to students, which appear to have self-fulfilling prophecy effects on them. The self-fulfilling prophecy effects of teacher expectations are an important, yet not adequately appreciated affective variable in second and foreign language learning. In this article we present the theoretical background on teacher's expectations for their students. We also describe the sources of teachers' expectations and the ways through which teachers communicate expectations to students. We finally deal with the pedagogical implications, offering suggestions about how teachers might become more successful in communicating high expectations.
\end{abstract}

Keywords: Self-fulfilling prophecy, Teacher expectations

\section{Introduction}

Research into the factors affecting academic performance has generated heated arguments and many factors have been found to influence student performance. However, it is widely accepted that in the analysis of the process of learning we need to consider the importance of both cognitive and affective variables. One of the most salient affective issues is the influence of teachers' expectations on pupils' attitudes towards learning, since evidence shows that teacher expectancies are correlated with student achievement (Dusek and Joseph, 1983).

The issue of expectations that teachers hold for their students in terms of their capability to learn (Alderman, 2004), and the concept of self-fulfilling prophecy as a "conceptual tool for understanding classroom achievement dynamics" (Covington, 1998:114) have been the focus of much attention in ESL/EFL contexts. It has been suggested that "teacher expectations often do play a role in student achievement" (Cooper, 2000: 339). Since the highly influential study of Robert Rosenthal and Lenore Jacobson (1968), many studies have addressed the issue of self-fulfilling prophecy in terms of an erroneous teacher expectation that leads to behaviour that "causes the expectation to come true" (Good and Brophy, 1994: 84). Rosenthal and Jacobson's research was designed examine the relationship between teacher expectations and student achievement. At the beginning of the school year they gave students an achievement test and informed teachers that based on the results of the examination, some students showed potential for high academic achievement in the forthcoming school year. However, these students were chosen randomly, not on the basis of their test scores. At the end of the school year, these students showed greater gains in IQ scores than other students in the same classrooms. The researchers' explanation was that the artificial expectations imposed on the teachers seem to have influenced teachers' behavior towards these students, in such a way that they enjoyed greater gain in achievement, and produced a 'self-fulfilling prophecy' effect (Kyriakou, 1997).

Despite the fact that the original Rosenthal and Jacobson's study received criticism because a) their results were not always confirmed in subsequent research by other researchers, and b) the study did not include classroom observation, their study nevertheless helped researchers realize and appreciate the role of affect in cognition. Moreover, it prompted them to focus on affective variables, such as self-esteem, inhibition, motivation and anxiety, in the study of second and foreign language acquisition (Andres, 2002).

Research has identified that the expectations that teachers have for their students in terms of behaviour and academic performance can have a strong impact on success in EFL/ESL learning, since they can act as self fulfilling prophesies (Zabel and Zabel, 1996). The concept of self-fulfilling prophecy as applied in educational contexts states that students will live up or down their teachers' "expectations, predictions, or preconceived notions" regarding their behavior and academic performance (Boehlert, 2005: 491).

At the core of the concept of self-fulfilling prophecy is the assumption that "one person's prediction of another person's behavior somehow comes to be realized" and that these expectations are communicated "in quite subtle and unintended ways" (Rosenthal and Jacobson, 2000: 286). In essence, this theory states that: a) teachers form 
different expectations for their students, b) these expectations are communicated to students, and c) teachers' expectations impact, either positively or negatively, on student behavior and performance.

The process of the self-fulfilling prophecy involves the following steps (Brophy, 1985; Covington, 1992). The first step involves the formation of expectations on the basis of some characteristics (e.g. students' previous achievement, socioeconomic background). Second, based on these expectations ,teachers behave differently to various students. For example, teachers may provide fewer clues to low achievers (Levin and Nolan, 1996). Third, teacher expectations are conveyed to students. Finally, students' behavior and achievement conforms to the initial teacher expectations.

Having established the theoretical background, in the next part of the article will present the sources of teachers' expectations. Then, we describe ways through which teachers communicate expectations to students. We finally deal with the pedagogical implications, offering suggestions about how teachers might become more successful in communicating high expectations.

\section{Factors that influence teachers' expectations}

Research has explored the complex factors and the many potential sources that affect the formation of teacher expectations. For example, Alderman (2004) provides a useful summary of the major sources of the expectations that teachers hold for their students based on research by Alvidrez \& Weinstein (1999) and Baron, Tom \& Cooper (1985). First, a significant source is related to teachers' beliefs about students' ability and their beliefs about intelligence. Alderman (2004: 174) explains that when teachers consider intelligence as a fixed student characteristic, they are more likely to label students as "smart or dumb and teach them according to the label". Weinstein argues that "one contributor to teacher judgments of ability is student performance" (Weinstein, 2002:54). Another source of teachers' expectations can be students' socioeconomic background, gender and ethnicity. Dusek and Joseph conducted a meta-analysis of research on teacher expectancies and conclude that student characteristics such as student's conduct in the school, race, classroom conduct, and social class "were related to teacher expectancies" (Dusek and Joseph, 1983: 327). Finally, students' test scores, and/or previous academic achievement can be influential in teachers' expectancies. Rivers (1980) quoted in (Dusek and Joseph, 1983) has found that in the early elementary school years an older sibling's performance may influence teachers' expectancies (either positive or negative) for a younger sibling's performance.

In addition, van Matre et al (2000) suggest that teachers held higher grade, graduation, and college attendance expectancies for females than for males and for middle-socio economic status (SES) than low-SES students.

\section{How teachers communicate expectations to students}

The formation of expectations does not necessarily mean than teachers communicate expectations to students. However, research has shown that a number of teachers do convey expectations, in a number of ways, sometimes with the teachers not being aware of it. The following teaching practices can convey differential expectations to students (Good and Weinstein, 1986 quoted in Alderman, 2004; Covington, 1998). First, some teachers are influenced by some student characteristic, label them as "less able", and use differential practices and behavior. This kind of teacher bias, however, can have a negative effect on their self-efficacy perceptions, that is, their personal judgments about their capabilities to organize and execute courses of action required to produce designated types of educational performances (Bandura, 1997; Zimmerman, 1999). Second self-fulfilling prophecy prone teachers are often in the habit of providing praise to low achievers for success in relatively simple tasks, while withholding blame for failure. Such strategies, though, can have a negative effect on their motivation and self-esteem, since they may be considered by students as an indication that the teacher has little confidence in their abilities and expects little from them (Thompson, 1997). Third, questioning strategies can convey the meaning that the teacher expects much or little from students. Many teachers adopt different questioning techniques depending on their assessments of student ability. For example, they often pay more attention to the answers of high achievers and wait longer before calling on someone else. Fourth, seating arrangements can convey expectations. Students labeled as "able" by the teacher are often seated in the first rows, while the students considered as less likely to have high performance usually occupy the last rows, thus becoming "invisible" by the teacher.

In addition to the above teaching behaviour, students who are considered more capable are often provided with more opportunities to perform publicly on meaningful tasks, have more choices in assignments, and are shown more respect as individuals by teachers. Teachers may also interact differently with high achievers. They often create a warmer socioemotional climate for brighter students, such as smiling more often to high achievers (Chaikin et al, 1974 quoted in Cooper, 2000). 
What is of great importance is that research has shown that students are "very well attuned" to behavioral cues from teachers (Covington, 1998:116). In other words, teacher expectations are communicated to students, who may live up to these expectations.

\section{Pedagogical implications}

The conclusion from the above theoretical framework is that suitable and appropriate teacher behaviour can communicate high expectations and boost student performance. The following specific teacher strategies for communicating positive expectations and raising expectations and students' performance are suggested by the work of several researchers.

Teachers can develop a positive classroom climate if they avoid forming differential expectations for students based on qualities such as gender, ethnicity, or parents' background (Schunk, Pintrich, and Meece, 2008:322). Similarly, they should avoid forming expectations based on such factors as record files, colleagues, information from other teachers or even the family's reputation (Good and Brophy, 1973:82).

Teachers can communicate expectancies for success by forming groups with students from all levels of language performance, and by not "marginalizing" low achievers. Trying not to "marginalize" students of lesser ability can be achieved through the implementation of the following classroom techniques. First by not supplying "answers impatiently to children of lesser ability" depriving them of opportunity to think and answer (Covington, 1998:115). Second, students should be given equally academically challenging tasks, and the same questioning strategies should be used for all students (Alderman, 2004). For example, some teachers tend to ask weak students questions which are at the lowest level (e.g. questions of knowledge). By contrast, they usually provide high achievers with opportunities to answer higher level questions (e.g. questions requiring an analysis or drawing a conclusion).

Apart from the above, the following behaviour can promote the communication of low expectations, and should thus be avoided (Levin and Nolan, 1996): a) calling on low-achieving students less often to answer questions, b) providing fewer clues to low achievers when they cannot answer questions, c) rarely expressing personal interest in low achievers, d) making social comparisons between students in front of the classroom, and e) smiling less often to weak students, staying farther away physically, or avoiding eye contact with them.

Moreover, the following suggestions can promote the communication of positive expectations. First, teachers should strive to create a kind of classroom culture in which language errors are seen as a normal part of the language acquisition process (Dörnyei, 2001; Young, 1999). Fostering the belief that mistakes are opportunities for learning (Schunk et al, 2008) should be given priority. Second, Teachers can use cooperative learning, such as students in small groups to complete projects. Cooperative learning, promotes peer-cooperation, purposeful communication, and interaction with authentic texts (Shokouli \& Zadeh-Dabbagh, 2009). Peer-cooperation can raise expectations, because it involves all students, emphasizes collaboration over competition and can foster the development of a friendly and supportive language community. Third, effective praise and feedback should "focus on the effort and care that the student put into the work on the gains in knowledge or skills", rather than orienting students "toward comparing themselves with others" (Brophy, 2004:168-169). Fourth, criticism should be instructive, aiming at helping students realize how they could do better, "rather than criticizing students themselves" or using personal criticism (Kyriacou, 1997: 83). In addition, teachers should not be influenced by student performance when providing criticism. Research has revealed that teachers are more prone to critisizing low-achieving students for a wrong answer than high-achieving students (Good \& Brophy, 1994). Fifth, Brophy (2004) suggests that portfolio assessment (sets of student work that show their progress over time) can be used, because this approach "focuses attention on quality rather than just grades" and can help them become "more oriented toward self-improvement over time".

Moreover, teachers need to show their students that a) they care for them and are committed to their progress, b) they are willing to listen to and value their opinions and feelings, c) they put priority on collaboration, rather than competition among students.

Finally, teachers should reassess their expectations from time to time, because even if their expectancies reflect accurate perceptions of students' abilities, their performance or behaviour may change in the course of the school year. Alderman (2004) called this kind of teacher behaviour as "the sustaining expectation effect", which occurs when a teacher has formed an expectation about a students, and although the student' behaviour has changed, the teacher "continues to respond to the student in the same way).

\section{Conclusion}

The self-fulfilling prophecy effects of teacher expectations constitute an important affective variable in second and foreign language learning, yet one which is often overlooked. While most teachers are eager to acknowledge 
that they form expectancies about their students' academic ability, cognitive skills, and success in mastering the second or foreign language, the majority believe that they do not treat students differently due to the expectations they have formed for them. Therefore, we feel that teachers need to become aware of the potential negative consequences of communicating low expectations, and adopt strategies that will help them raise expectations and students' performance.

In this context, the overall aim of this article was not to provide a bag of tricks that teachers can use in their classrooms. Every teaching context is different, and there is no such thing as "universal" guidelines. Instead, we aimed at making teachers aware of the negative as well as positive consequences of the expectations that they form about students' behaviour and performance. We suggest that forming expectations is an inevitable part of the teaching process. Teachers should acknowledge this and need to know how they can become more successful in communicating high expectations.

It should also be emphasized that the suggestions and techniques outlined above are general and teachers need to adapt them in order to take into account their specific "classroom ecosystem" (Zabel \& Zabel, 1996: xxi). Teachers should also bear in mind that even if the above components of communicating positive expectations and raising students' performance are essential by themselves, conveying high expectations for all students is a complex mixture of all the features described.

\section{References}

Alderman, M. K. (2004). Motivation for achievement: possibilities for teaching and learning. Mahwah NJ: Lawrence Erlbaum

Alvidrez, J., \& Weinstein, R. S. (1999). Early teacher perceptions and later student academic achievement. Journal of Educational Psychology, 91, 731-746.

Andres, V. (2002). The Influence of Affective Variables on EFL/ESL Learning and Teaching, The Journal of the Imagination In Language Learning and Teaching,

[Online] Available: http://www.njcu.edu/CILL/vol7/andres.html (29 January 2010)

Bandura, A. (1997). Self-efficacy: The exercise of control. New York: Freeman.

Baron, R. M., Tom, D. Y. H., \& Cooper, H. M. (1985). Social class, race and teacher expectations. In J. B. Dusek (Ed.) Teacher expectations (pp. 251-269). Hillsdale, NJ: Lawrence Erlbaum Associates.

Boehlert, M. (2005). Self-fulfilling prophecy. In S. W. Lee (Ed.), Encyclopedia of school psychology, Thousand Oaks, CA: Sage.

Brophy, J. (2004). Motivating students to learn. New Jersey: Lawrence Erlbaum.

Brophy, J. E. (1985). teacher-student interaction. In J. B. Dusek, V. C. Hall and W. J. Meyer, (Eds.), Teacher expectancies (pp. 303-327). Hillsdale, NJ: Lawrence Erlbaum.

Chaikin, A., Sigler, E., \& Derlega, V. (1974). Nonverbal mediators of teacher expectancy effects, Journal of Personality and Social Psychology, 30(1), 144-149.

Cooper, H. M. (2000). Pygmalion grows up. In P., K.Smith, \& A.D. Pellegrini Psychology of Education: major themes (pp. 338-364). London: Routledgefalmer.

Covington, M. V. (1998). The will to learn: a guide for motivating young people. Cambridge University Press: Cambridge.

Covington, M. V. (1992). Making the grade: a self-worth perspective on motivation and school reform, Cambridge University Press: Cambridge.

Dörnyei, Z. (2001). Motivational Strategies in the Language Classroom. Cambridge: Cambridge University Press.

Dusek, J. B., \& Joseph, G. (1983). The bases of teacher expectancies: A meta-analysis. Journal of Educational Psychology 75(3), 327-346.

Good, T. L., \& Brophy, J. E. (1973). Looking in classrooms (1st edition). Harper \& Row: New York.

Good, T. L., \& Brophy, J. E. (1994). Looking in classrooms (6th edition). Harper \& Row: New York.

Good, T. L., \& Weinstein, R. (1986). Teacher expectations: A framework for exploring classrooms. In K. K. Zumwalt (Ed.), Improving teaching (The 1986 ASCD Yearbook), (pp. 63-85). Alexandria, VA: Association for Supervision and Curriculum Development. 
Kyriacou, C. (1997). Effective teaching in schools: theory and practice (2nd edition). Cheltenham, UK: Nelson Thornes Ltd.

Levin, J., \& Nolan, J. F., (1996). Principles of Classroom Management: A Professional Decision-Making Model (2nd edition). USA: Allyn and Bacon.

Rivers, J. (1980). Older siblings as bases of teacher expectations. Dissertation Abstracts International, 40:4253-A.

Rosenthal, R., \& Jacobson, L. (1968). Pygmalion in the classroom: Teacher expectation and pupils' intellectual development. New York: Holt, Rinehart \& Winston.

Rosenthal, R., \& Jacobson, L. (2000). Teacher expectations for the disadvantaged. In P., K.Smith, and A.D. Pellegrini (Eds.), Psychology of Education: major themes (pp. 286-291). Routledgefalmer: London.

Schunk, D. H., Pintrich, P. R., \& Meece, J. L. (2008). Motivation in Education: Theory, Research, and Applications (3rd edition). Upper Saddle River, NJ: Pearson Education, Inc.

Shokouli, H., \& Zadeh-Dabbagh, S. (2009). Punctuation and spelling in learners' writing. Asian EFL Journal, 40.

[Online] Available: http://www.asian-efl-journal.com/pta-November-2009.pdf (December 20, 2009)

Thompson, T. (1997). Do we need to train teachers how to administer praise? Self-worth theory says we do. Learning and Instruction, 7, 49-63.

Van Matre, J. C., Valentine, J. C., \& Cooper, H. (2000). Effect of Students' After-School Activities on Teachers' Academic Expectancies. Contemporary Educational Psychology, 25, 167-183.

Weinstein, R. S. (2002). Reaching higher: the power of expectations in schooling, Cambridge, MA: Harvard University Press

Young, D. J. (1999). Giving priority to the language learner first. In D. J. Yound (Ed.), Affect in foreign language and second language learning: a practical guide to creating a low-anxiety classroom atmosphere. United States of America: McGraw-Hill.

Zabel, R.H., \& Zabel, M.K. (1996). Classroom management in context: orchestrating positive learning environments. USA: Houghton Mifflin Company.

Zimmerman, B. J. (1999). Self-efficacy and educational development. In A. Bandura, (Ed.), Self-efficacy in changing societies. Cambridge: Cambridge University Press. 